\title{
D-Psicose Is a Rare Sugar That Provides No Energy to Growing Rats
}

\author{
Tatsuhiro MaTSuo*, Hiroo SuzuKI, Mineo HaSHiguCHI \\ and Ken IZUMORI \\ Faculty of Agriculture, Kagawa University, 2393 Ikenobe, \\ Miki-cho, Kita-gun, Kagawa 761-0795, Japan
}

(Received July 29, 2001)

\begin{abstract}
Summary D-Psicose (D-ribo-2-hexulose), a C-3 epimer of D-fructose, is present in small quantities in commercial carbohydrate complexes and agricultural products. We have previously reported that D-psicose supplements in diets suppressed hepatic lipogenic enzyme activity. The lower fat accumulation in rats fed D-psicose may be due to lower lipogenesis in the liver. The present study examined the energy available in D-psicose for rat growth. Male Wistar rats received $7 \mathrm{~g}$ daily of a basal diet to which fixed amounts of sucrose, $\mathrm{D}$-fructose, or D-psicose $(0.5-2.0 \mathrm{~g})$ were added for $20 \mathrm{~d}$. Body weight gain and body energy gain increased with increases in sucrose and D-fructose, but not with D-psicose. One gram of sucrose, Dfructose, and D-psicose produced a net energy gain of $2.29,1.76$, and $0.007 \mathrm{kcal}$, respectively. The efficiency of energy deposition from D-psicose was $0.3 \%$ that of sucrose. The energy value of D-psicose was effectively zero. These results suggest that D-psicose is a rare sugar providing zero energy that may be useful in sweeteners for obese people as an aid for weight reduction.
\end{abstract}

Key Words D-psicose, sucrose, available energy, body energy, rat

A method of body weight control that has gained wide acceptance is the reduction of the energy content of food. Reduced fat or fat-free products are now commonplace in grocery stores in many advanced nations. Efforts have also been made to find carbohydrates with reduced energy content. Because at least half of food energy comes from carbohydrates, a significant reduction in food energy can potentially be achieved by the introduction of low-energy carbohydrates. In recent publications (1), the energy content of commonly used dietary fibers and sugar alcohols has been reported to vary from 0 to $3 \mathrm{kcal} / \mathrm{g}$. The combined intake of these carbohydrates is, limited however, by the extent to which they are tolerated in the gastrointestinal tract (2-4).

For nearly two decades, the isomers of monosaccharides ( $\mathrm{L}$-sugars or D-tagatose) have been developed as alternative carbohydrate sweeteners and bulking agents (5-7). However, D-psicose (D-ribo-2-hexulose), a C-3 epimer of $\mathrm{D}$-fructose, has never been thoroughly studied as a sugar substitute because D-psicose is a sweet rare sugar present in very small quantities in natural ingredients and in commercial mixtures of D-glucose and Dfructose obtained from the hydrolysis of sucrose or the isomerization of D-glucose (8). In the previous study, when D-psicose was orally injected into fasting rats, it was retained by the urine $(37 \%)$, feces $(13 \%)$, breath (15\%), and carcass (39\%) (9). These findings suggested that $\mathrm{D}$-psicose might have low available energy, even

* To whom correspondence should be addressed.

E-mail:matsuo@ag.kagawa-u.ac.jp though a portion was absorbed into the animal's metabolic system.

Recently, we developed a new method to produce Dpsicose enzymatically on a large scale (10). Moreover, we have suggested that D-psicose supplements suppress hepatic lipogenic enzyme activity and reduce abdominal fat accumulation compared to D-glucose or D-fructose in rats (11). However, the efficiency of D-psicose utilization as energy was not known. In this study, we investigated the available energy of $\mathrm{D}$-psicose for rat growth and found that in rats the energy value of D-psicose is effectively zero.

\section{Experimental}

Animals and experimental design. The experimental design was essentially the same as that reported by Donato and Hegsted (12), or Suzuki et al. (13). Seventy male Wistar rats (3 wk old) were obtained from Japan SLC, Inc. (Shizuoka, Japan). Rats were fed CE-2, commercial rodent diet (CLEA Japan, Tokyo), and water ad libitum for $3 \mathrm{~d}$ and a basal diet for the next $4 \mathrm{~d}$. The basal diet contained the following ingredients, in grams per kilogram: casein, 600; cornstarch, 195; corn oil, 50; cellulose, 50; mineral mixture, 70; vitamin mixture, 20 (both mixtures are based on the AIN-76); choline chloride, 5; and DL-methionine, 10. The animals were randomly divided into 14 groups (see Table 1). One group of rats was killed at the beginning (day 0 control) for an analysis of body composition. The remaining animals were individually caged at $24 \pm 1^{\circ} \mathrm{C}$, with light from $08: 00$ to $20: 00 \mathrm{~h}$. Each group of rats received $7 \mathrm{~g}$ daily of the basal diet to which a fixed 
amount of sucrose, D-fructose, or D-psicose (0.5-2.0 g of appropriate sweetener, see Table 2) was added for $20 \mathrm{~d}$. The $2 \mathrm{~g}$ dietary D-psicose was chosen as the maximum amount of the supplement because it produced the least diarrhea, a side effect of the supplementation. Feces were collected during the last $7 \mathrm{~d}$ to determine nitrogen excretion. On the final day of the experiment, the rats were fasted overnight $(12 \mathrm{~h})$ and killed by neck dislocation. Residual food in the digestive tracts was discarded, and carcass samples were stored at $-20^{\circ} \mathrm{C}$ until an analysis of carcass composition.

Analyses. Carcass fat and protein were analyzed by the method reported by Michelsen and Anderson (14).
Feces were freeze-dried, weighed, and ground to powder to determine nitrogen secretion by the microkjeldahl technique.

To calculate the change in body energy content of each animal over the 20-d period, the average energy content of the animals killed at the beginning (day 0 controls) was calculated $(12,13)$. These values multiplied by the starting weight of each animal yielded the estimated energy content, which was then subtracted from the value at $20 \mathrm{~d}$. Body fat was assumed to contain $9.4 \mathrm{kcal} / \mathrm{g}$, and body protein was assumed to contain $4.0 \mathrm{kcal} / \mathrm{g}(12,13)$.

Data analysis. All data were analyzed by a factorial
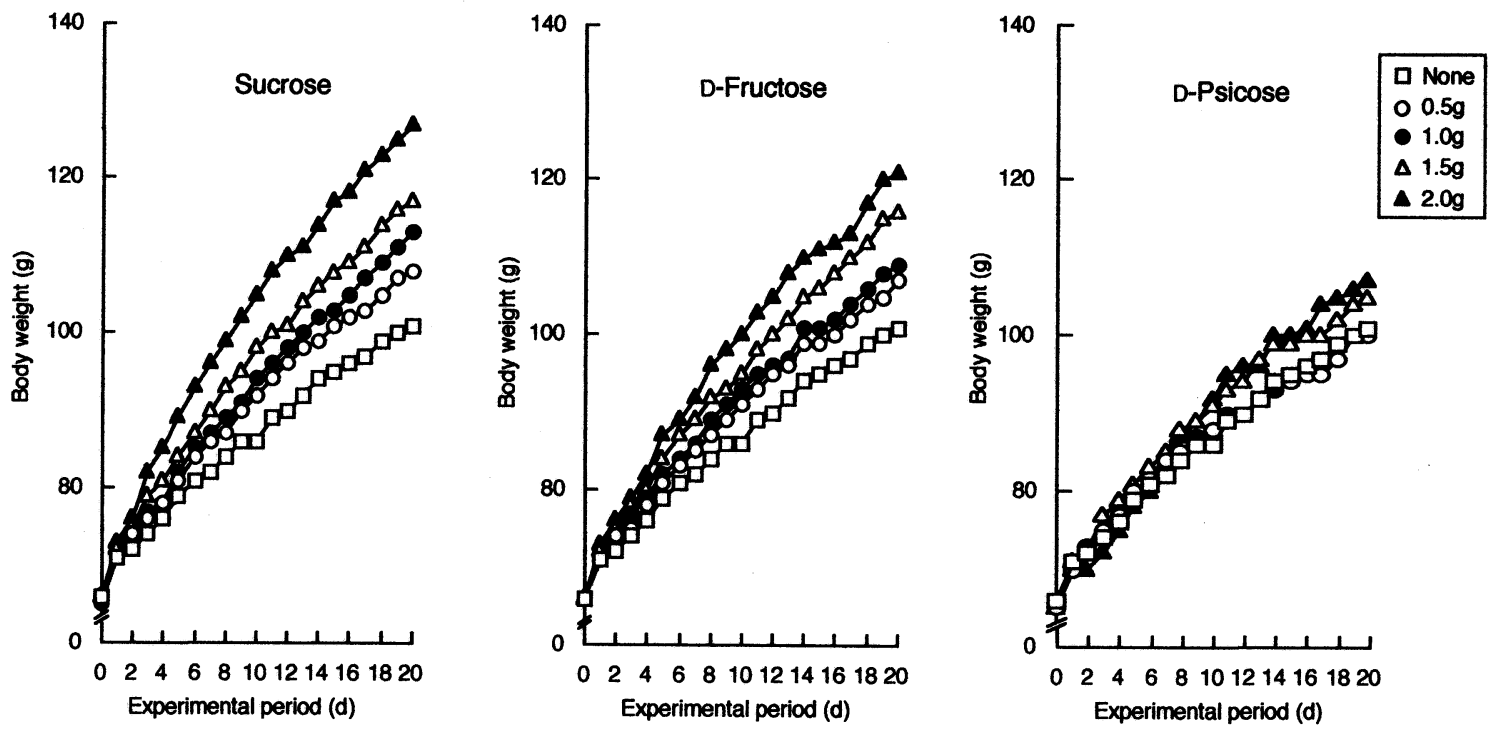

Fig. 1. Changes in body weight of rats fed diets with various levels of sucrose, D-fructose, and D-psicose for $20 \mathrm{~d}$. Data represent average values $(n=5)$. Range of SE was $1.7-3.8 \mathrm{~g}$ for all points (data not shown).

Table 1. Body composition and body energy of rats with various levels of sucrose, D-fructose, and D-psicose supplementation.

\begin{tabular}{|c|c|c|c|c|c|c|c|c|}
\hline \multirow[b]{2}{*}{ Group } & \multirow{2}{*}{ Supplement } & \multicolumn{2}{|c|}{ Amount $^{1}$} & \multicolumn{3}{|c|}{ Body composition ${ }^{2}$} & \multirow{2}{*}{$\begin{array}{c}\text { Total } \\
\text { body } \\
\text { energy } \\
\text { (kcal/rat) }\end{array}$} & \multirow{2}{*}{$\begin{array}{l}\text { Increase } \\
\text { in body } \\
\text { energy } \\
\text { (kcal/rat) }\end{array}$} \\
\hline & & $\begin{array}{l}\text { Daily } \\
\text { (g) }\end{array}$ & $\begin{array}{c}\text { Total } \\
\text { (g) }\end{array}$ & $\begin{array}{l}\text { Weight }^{4} \\
\text { (g) }\end{array}$ & $\begin{array}{l}\text { Protein } \\
\text { (g) }\end{array}$ & $\begin{array}{l}\text { Fat } \\
(\mathrm{g})\end{array}$ & & \\
\hline 1 & None & 0.0 & 0 & $88.4 \pm 1.8^{\mathrm{e}}$ & 20.2 & 7.94 & 155.5 & $71.9 \pm 3.8^{\mathrm{e}}$ \\
\hline 2 & Sucrose & 0.5 & 10 & $99.1 \pm 3.3^{\mathrm{cd}}$ & 22.5 & 11.2 & 195.8 & $112.2 \pm 3.5^{\mathrm{d}}$ \\
\hline 3 & Sucrose & 1.0 & 20 & $100.7 \pm 4.0^{\mathrm{cd}}$ & 22.1 & 13.6 & 216.0 & $132.4 \pm 7.1^{b c}$ \\
\hline 4 & Sucrose & 1.5 & 30 & $106.4 \pm 1.7^{\mathrm{bc}}$ & 22.8 & 16.4 & 245.4 & $161.7 \pm 4.8^{\mathrm{a}}$ \\
\hline 5 & Sucrose & 2.0 & 40 & $116.2 \pm 1.4^{\mathrm{a}}$ & 25.8 & 15.1 & 245.5 & $161.9 \pm 3.3^{a}$ \\
\hline 6 & D-Fructose & 0.5 & 10 & $94.7 \pm 3.1^{\mathrm{de}}$ & 21.6 & 11.3 & 192.0 & $108.4 \pm 3.3^{\mathrm{d}}$ \\
\hline 7 & D-Fructose & 1.0 & 20 & $98.0 \pm 5.2^{\mathrm{d}}$ & 21.5 & 11.3 & 192.2 & $108.6 \pm 4.0^{\mathrm{d}}$ \\
\hline 8 & D-Fructose & 1.5 & 30 & $104.6 \pm 2.7^{b c}$ & 23.3 & 12.1 & 207.2 & $123.6 \pm 3.7^{\mathrm{c}}$ \\
\hline 9 & D-Fructose & 2.0 & 40 & $111.9 \pm 2.9^{\mathrm{ab}}$ & 24.2 & 14.5 & 233.0 & $149.4 \pm 3.5^{\mathrm{ab}}$ \\
\hline 10 & D-Psicose & 0.5 & 10 & $89.9 \pm 2.3^{\mathrm{e}}$ & 20.5 & 8.32 & 160.3 & $76.7 \pm 4.3^{\mathrm{e}}$ \\
\hline 11 & D-Psicose & 1.0 & 20 & $89.3 \pm 3.2^{\mathrm{e}}$ & 19.9 & 8.76 & 162.1 & $78.5 \pm 5.2^{\mathrm{e}}$ \\
\hline 12 & D-Psicose & 1.5 & 30 & $88.9 \pm 2.2^{\mathrm{e}}$ & 20.2 & 8.52 & 160.7 & $77.1 \pm 2.3^{\mathrm{e}}$ \\
\hline 13 & D-Psicose & 2.0 & 40 & $91.4 \pm 2.2^{\mathrm{de}}$ & 21.0 & 7.65 & 155.7 & $72.1 \pm 4.0^{\mathrm{e}}$ \\
\hline 14 & Day 0 control & & & $58.0 \pm 2.1^{\mathrm{f}}$ & 12.7 & 3.48 & 83.6 & \\
\hline
\end{tabular}

\footnotetext{
${ }^{1}$ Over 20-d period.

2 The values of body composition and total body energy are means for 5 rats.

${ }^{3}$ Carcass calories minus day 0 control (mean \pm SE for 5 rats).

${ }^{4}$ Within a column, the values with different superscripts are significantly different among groups $(p<0.05)$.
} 
analysis of variance (ANOVA) and Fisher's PLSD tests. Differences were considered statistically significant at $p<0.05$.

\section{Results and Discussion}

Body weight gain and body energy gain increased with the increase in sucrose and D-fructose, whereas these were not affected by increasing D-psicose (Fig. 1 and Table 1).

From increases in body energy (Table 1), regression lines were calculated according to the method of Donato and Hegsted (12) (Fig. 2). The horizontal axis corresponds to the total amount of supplement consumed over $20 \mathrm{~d}$; thus the slope of the line represents the energy deposition per gram of supplement consumed. One gram of sucrose, D-fructose, and D-psicose

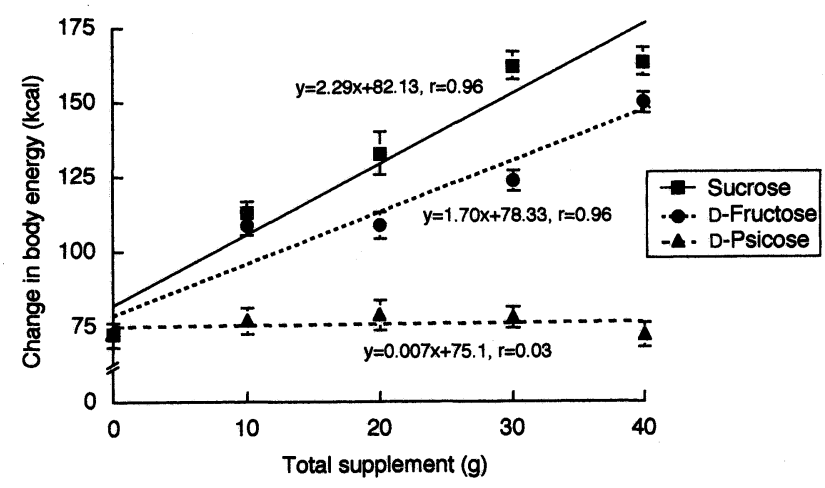

Fig. 2. Change in body energy content of rats fed diets with various levels of sucrose, D-fructose, and D-psicose. Values are means \pm SE for 5 rats. The available energy of D-psicose for rat growth was estimated according to the method of Donato and Hegsted (12). Regression lines were calculated from the increases in body energy given in Table 1 . produced a net gain of $2.29,1.76$, and $0.007 \mathrm{kcal}$, respectively. The efficiency of energy deposition from Dpsicose was $0.3 \%(0.007 / 2.29=0.003)$ that of sucrose. The energy value of D-psicose was effectively zero.

Cecal contents, feces and nitrogen excretion increased with an increase in D-psicose, but these were not affected by increasing sucrose or D-fructose (Table 2 ). Regression lines were calculated from the data shown in Table 2 (Fig. 3). The horizontal axis corresponds to the daily supplement. A positive correlation was observed between nitrogen excretion and daily Dpsicose, whereas nitrogen exertion was not affected by increasing the D-fructose supplementation (Fig. 3).

We have shown here that body energy accumulation during growth was lower in rats fed a diet with D-psicose than in rats fed diets with sucrose and D-fructose. The available energy of D-psicose for rat growth was effectively $0 \mathrm{kcal} / \mathrm{g}$, compared with $3.94 \mathrm{kcal} / \mathrm{g}$ for su-

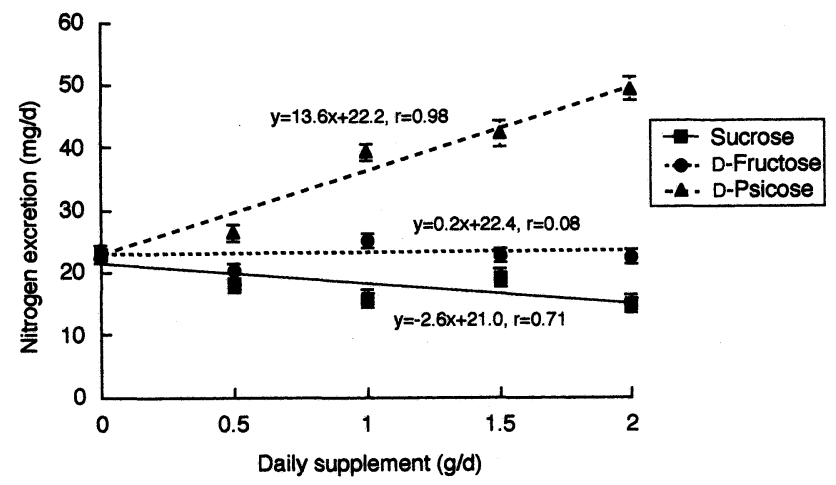

Fig. 3. Change in daily fecal nitrogen excretion of rats fed diets with various levels of sucrose, D-fructose, and D-psicose. Values are means \pm SE for 5 rats. Regression lines were calculated from the data for nitrogen excretion given in Table 2.

Table 2. Cecal contents, feces, and nitrogen excretion of rats with various levels of sucrose, D-fructose, and D-psicose supplementation.

\begin{tabular}{|c|c|c|c|c|c|c|c|}
\hline \multirow[b]{2}{*}{ Group } & \multirow[b]{2}{*}{ Supplement } & \multicolumn{2}{|c|}{ Amount $^{1}$} & \multirow{2}{*}{$\begin{array}{c}\text { Cecal } \\
\text { contents }^{2} \\
(\mathrm{~g})\end{array}$} & \multicolumn{3}{|c|}{ Excretion $^{2}$} \\
\hline & & $\begin{array}{l}\text { Daily } \\
\text { (g) }\end{array}$ & $\begin{array}{l}\text { Total } \\
\text { (g) }\end{array}$ & & $\begin{array}{l}\text { Feces } \\
(\mathrm{mg} / \mathrm{d})\end{array}$ & $\begin{array}{c}\text { Nitrogen } \\
(\%)\end{array}$ & $\begin{array}{c}\text { Nitrogen } \\
(\mathrm{mg} / \mathrm{d})\end{array}$ \\
\hline 1 & None & 0.0 & 0 & $12.8 \pm 0.8^{b c}$ & $658 \pm 9^{c d}$ & $3.48 \pm 0.13^{\mathrm{d}}$ & $22.9 \pm 0.9^{\text {de }}$ \\
\hline 2 & Sucrose & 0.5 & 10 & $9.0 \pm 1.2^{\mathrm{cd}}$ & $430 \pm 6^{\mathrm{e}}$ & $4.26 \pm 0.08^{c}$ & $18.3 \pm 0.6^{\mathrm{ef}}$ \\
\hline 3 & Sucrose & 1.0 & 20 & $12.1 \pm 1.6^{\mathrm{c}}$ & $317 \pm 4^{f}$ & $5.03 \pm 0.03^{b}$ & $15.9 \pm 0.3^{f}$ \\
\hline 4 & Sucrose & 1.5 & 30 & $10.8 \pm 0.8^{c}$ & $331 \pm 6^{f}$ & $5.77 \pm 0.17^{\mathrm{a}}$ & $19.1 \pm 0.7^{\mathrm{e}}$ \\
\hline 5 & Sucrose & 2.0 & 40 & $11.1 \pm 2.0^{c}$ & $310 \pm 8^{f}$ & $5.16 \pm 0.21^{b}$ & $15.0 \pm 0.8^{\mathrm{f}}$ \\
\hline 6 & D-Fructose & 0.5 & 10 & $12.3 \pm 0.7^{\mathrm{c}}$ & $668 \pm 8^{c}$ & $3.06 \pm 0.04^{\mathrm{f}}$ & $20.4 \pm 0.3^{\mathrm{e}}$ \\
\hline 7 & D-Fructose & 1.0 & 20 & $11.0 \pm 1.5^{\mathrm{c}}$ & $685 \pm 10^{c}$ & $3.68 \pm 0.05^{\mathrm{d}}$ & $25.2 \pm 0.4^{\mathrm{d}}$ \\
\hline 8 & D-Fructose & 1.5 & 30 & $11.1 \pm 1.4^{\mathrm{c}}$ & $671 \pm 8^{c}$ & $3.38 \pm 0.04^{\mathrm{e}}$ & $22.7 \pm 0.5^{\mathrm{e}}$ \\
\hline 9 & D-Fructose & 2.0 & 40 & $9.3 \pm 0.5^{\mathrm{cd}}$ & $660 \pm 6^{c}$ & $3.40 \pm 0.06^{\mathrm{de}}$ & $22.3 \pm 1.2^{\mathrm{e}}$ \\
\hline 10 & D-Psicose & 0.5 & 10 & $10.1 \pm 1.2^{\mathrm{c}}$ & $713 \pm 20^{c}$ & $3.70 \pm 0.06^{\mathrm{d}}$ & $26.4 \pm 1.2^{\mathrm{c}}$ \\
\hline 11 & D-Psicose & 1.0 & 20 & $11.3 \pm 0.9^{c}$ & $786 \pm 27^{b}$ & $4.98 \pm 0.06^{b}$ & $39.2 \pm 1.5^{b}$ \\
\hline 12 & D-Psicose & 1.5 & 30 & $16.4 \pm 1.0^{\mathrm{ab}}$ & $851 \pm 49^{a}$ & $4.96 \pm 0.12^{b}$ & $42.1 \pm 2.0^{b}$ \\
\hline 13 & D-Psicose & 2.0 & 40 & $16.0 \pm 1.0^{\mathrm{ab}}$ & $831 \pm 30^{\mathrm{a}}$ & $5.91 \pm 0.06^{\mathrm{a}}$ & $49.1 \pm 1.9^{\mathrm{a}}$ \\
\hline
\end{tabular}

\footnotetext{
${ }^{1}$ Over 20-d period.
}

${ }^{2}$ Values are means \pm SE for 5 rats. Within a column, the values with different superscripts are significantly different among groups $(p<0.05)$. 
crose (12). These caloric values for this sweetener are largely responsible for its effects on body fat content (Table 1). The results support our previous findings that abdominal fat accumulation was mimimally affected by an intake of diets with D-psicose (11).

Whistler et al. (9) reported that $15.1 \%$ of radioactivity was exhaled as $\left[{ }^{14} \mathrm{C}\right]$ carbon dioxide within $72 \mathrm{~h}$ after oral administration of D-[U- $\left.{ }^{14} \mathrm{C}\right]$ psicose $(2 \mu \mathrm{Ci})$ by stomach tube. This implies either increased energy expenditure or incomplete coupling between D-psicose oxidation and ATP generation (15). Davies et al. (16) and Livesey and Brown (17) demonstrated that the viscous polysaccharide guar gum supplied energy via fermentation, but equally increased energy expenditure, resulting in a net metabolizable energy value close to zero. They suggested that contributing to the increased energy expenditure on the consumption of guar gum was an increase in the size of digestive organs (18). In the present study, since dietary D-psicose increased cecal contents and feces excretion, D-psicose could be a fermentative saccharide similar to a soluble fiber. Thus Dpsicose, like the guar gum mentioned above $(16,17)$, appears not to supply useful energy.

On the other hand, a positive correlation was observed between nitrogen excretion and daily D-psicose supplement. We do not know if this result is caused by suppressing the absorption of amino acids or by increasing the excretion of bacteria corpses with fermentation. The detailed mechanism remains to be clarified.

In conclusion, the present study demonstrated that Dpsicose is a sweet monosaccharide providing zero energy to growing rats. This finding suggests that D-psicose may be useful in sweeteners for obese people as an aid in weight reduction.

\section{Acknowledgments}

This study was performed with Special Coordination Funds for Promoting Science and Technology of the Science and Technology Agency of the Japanese Government.

\section{REFERENCES}

1) Livesey G. 1992. The energy values of dietary fiber and sugar alcohols for man. Nutr Res Rev 5: 61-84.

2) Levin GV, Zehner LR, Saunders JP, Beadle JR. 1995. Sugar substitutes: their energy values, bulk characteristics, and potential health benefits. Am J Clin Nutr 62 (Suppl): 1161S-1168S.
3) Ellis FW, Krantz JD Jr. 1941. Sugar alcohols: XXII, metabolism and toxicity studies with mannitol and sorbitol in man and animals. J Biol Chem 141: 147-154.

4) Hiele M, Ghoos Y, Rutgeerts P, Vantrappen G. 1986. Metabolism of erythritol in humans-comparison with glucose and lactitol. Br J Nutr 69: 169-176.

5) Levin G. 1986. L-Sugars: Lev-O-Cal. In: Alternative Sweeteners (Nabors L, Gelardi R, eds), p 155-164. Marcel Dekker, New York.

6) Levin G, Zehner L. 1991. L-Sugars: Lev-O-Cal. In: Alternative Sweeteners, 2nd ed (Nabors L, Gelardi R, eds), p 117-125. Marcel Dekker, New York.

7) Livesey G. 1990. The energy values of unavailable carbohydrates and diets: an inquiry and analysis. Am J Clin Nutr 51: 613-637.

8) Cree GM, Perlin AS. 1968. O-Isopropylidene derivatives of D-allulose (D-psicose) and D-erythro-hexopyranose2,3-diulose. Can J Biochem 46: 765-770.

9) Whistler RL, Singh PP, Lake WC. 1974. D-Psicose metabolism in the rat. Carbohydr Res 34: 200-202.

10) Itoh H, Sato T, Izumori K. 1995. Preparation of D-psicose from D-fructose by immobilized D-tagatose 3epimerase. J Ferment Bioeng 80: 101-103.

11) Matsuo T, Baba $Y$, Hashiguchi $M$, Takeshita K, Izumori K, Suzuki H. 2001. Dietary D-psicose, a C-3 epimer of Dfructose, suppresses hepatic lipogenic activation in rats. Asia Pacific J Clin Nutr 10: 233-237.

12) Donato K, Hegsted DM. 1985. Efficiency of utilization of various sources of energy for growth. Proc Natl Acad Sci USA 82: 4866-4870.

13) Suzuki M, Nishiyama K, Ohmori S, Yoshioka M, Shimomura Y. 1992. Effects of dietary palatinose and reduced-palatinose on body energy composition. J Clin Biochem Nutr 13: 117-125.

14) Michelsen O, Anderson AA. 1959. A method for preparing intact animals for carcass analysis. J Lab Clin Med 53: 282-290.

15) Livesey G, Brown JC. 1996. D-Tagatose is a bulk sweetener with zero energy determined in rats. J Nutr 126: 1601-1609.

16) Davies IR, Brown JC, Livesey G. 1991. Energy values and energy balance in rats fed on supplements of guar gum or cellulose. Br J Nutr 65: 415-433.

17) Livesey G, Brown JC. 1995. Whole-body metabolism is not restricted to D-sugars as energy metabolism of Lsugars fits a computational model in rats. J Nutr 125: 3020-3029.

18) Brown JC, Livesey G. 1994. Energy balance and expenditure while consuming guar gum at various fat intakes and ambient temperatures. Am I Clin Nutr 60: 955-964. 